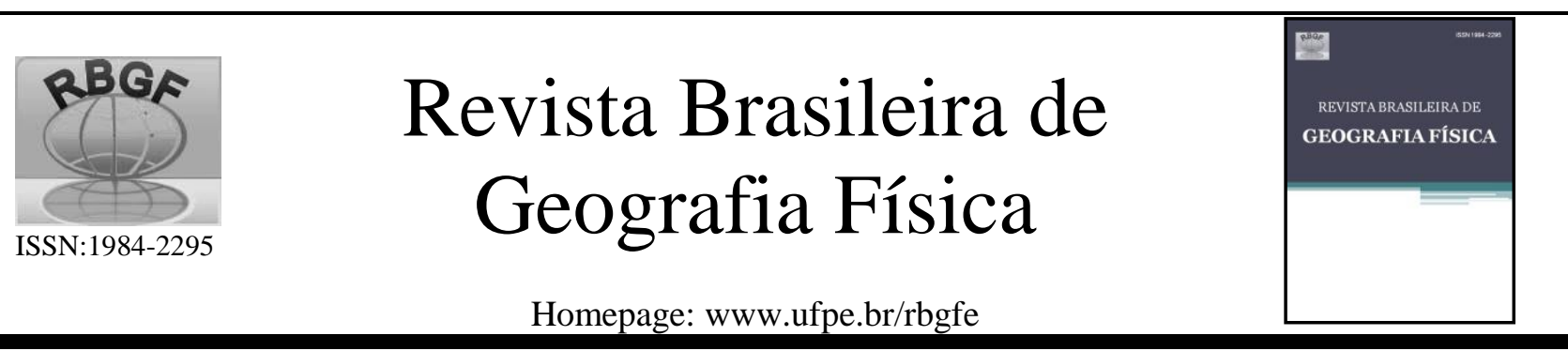

\title{
Analysis of the basin of the uruguay river through automated geomorphometric classification of the landforms elements
}

Luís Eduardo de Souza Robaina- Universidade Federal de Santa Maria, Corresçondent Author e-mail: lesrobaina@yahoo.com.br Romario Trentin- Universidade Federal de Santa Maria. E-mail: romario.trentin@gmail.com

Received paper in 08/14/2018 and accept in 11/14/2018

\begin{abstract}
A B S T R A C T
The present work aims to determine the landforms, from the automated classification generating geomorphons for the Uruguay River basin, identifying the distribution of these elements in the high, medium and low course. The landforms elements called geomorphons were obtained analyzing the textural similarity of the Digital Elevation Models (DEM), which present variations more or less gray levels between neighboring cells. After the generation of the landforms elements, the data were organized in Geographic Information Systems (GIS) to define the area and percentage of each unit, as well as the occurrence of elements in each sector of the river.
\end{abstract}

Keywords: geomorphons; Uruguay River basin; automated classification.

\section{Análise da bacia do rio uruguay através da classificação geomorphométrica automática dos elementos de terrenos}

\section{R E S U M O}

O presente trabalho teve como objetivo determinar as formas de relevo a partir de uma classificação automatizada gerando geomorfons da bacia do rio Uruguai, identificando os elementos de terreno no alto, médio e baixo curso. Os elementos de terreno denominados de geomorfons foram obtidos usando analisando a similaridade textural de um Modelo Digital de Elevação (MDE) com a presença de maior ou menor tons de cinza entre as células vizinhas. Após a geração dos elementos de terreno, os dados são organizados em um Sistema de Informações Geográfica (SIG) para definir a área e percentual de cada unidade, como também, as ocorrências dos elementos em cada setor do rio.

Palavras-chaves: geomorfons; bacia do rio Uruguai; classificação automatizada

\section{Introduction}

The landforms study is a basic instrument for geomorphological studies and widely used in obtaining information about the dynamics of the landscape.

The dissemination of the Digital Elevation Models (DEM) and the use of the tools of the Geographic Information Systems (GIS), in the spatial analysis of the landforms, has driven the analyzes from automated classification.

Most of the existing methods of automated classification of the earth's structure have their roots in differential geometry. The existing approaches focus on the best way to use the information contained in the geomorphometric variables and in the choice of the target units of classification.

Macmillan; Shary (2009) emphasize that all methods of automatic prediction of classes of geomorphic spatial entities are based on the creation of rules for the establishment of predictive relations between the input variables and the resulting classes.

Wood (1996) classifies six Terrain Forms (TFs): Plane, Channel, Ridge, Pass, Peak, and Pit. The method considers a specific combination of the pairs of Longitudinal / Transverse and Minimum / Maximum curves depending on the slope of the region to be classified.

Schmidt; Hewitt (2004) developed a procedure that allows to obtain different TEs (Terrain Elements), using as criterion the position of the landscape, dividing it into flat areas and dissected areas from the tangential, vertical, minimum and maximum curvature.

Using plane curvature and vertical curvature Drâgut, Blaschke, (2006) have chosen to 
segment the relatively homogeneous Elevation Models at various geomorphological levels.

Based on three morphometric variables: slopes, slope convexity and surface texture Iwahashi; Pike, (2007) present an automated topographic classification method, without supervision.

Jasiewicz; Stepinski, (2013), made an analogy between the textural classification of an image, based on the gray-scale spatial arrangement, comparing it with the specified distribution of the elevation values of the DEM for a given region, with spatial arrangement of elevation. They used the concept of Local Ternary Patterns (LTP) (LIAO, 2010) to identify landforms, called geomorphons. Each of these elements can be expressed by a number of different geomorphons. The authors generated a map with the 10 most common namely: flat, peak, ridge, shoulder, spur, slope, hollow, footslope, valley, pit. To demonstrate a practical application of the geomorphons method, the authors generated the geomorphometric map of the country Poland, noting that the spatial extensions of these varied identifiable by the geomorphons coinciding with the physiographic partition of Poland.

In Brazil, automated classification of landforms were developed in the state of Paraná by SILVEIRA (SILVEIRA, 2015), in the central region of Serra do Mar Paranaense by SILVEIRA and SILVEIRA, 2016. Using the methodology proposed by Jasiewicz \& Stepinski (2013), Robaina et al $(2016 ; 2017)$ defined compartments of landforms for the Rio Grande do Sul and Tocantins.

The present work aims to determine the landforms, from the automated classification generating geomorphons for the Uruguay River basin, identifying the distribution of these elements in the high, medium and low course.

\section{Methodology}

The cartographic bases used to define the limits of the hydrographic basin were the data of the Digital Elevation Model originated from the Shuttle Radar Topography Mission (SRTM), made available by the United States Geological Survey (US GEOLOGICAL SURVEY, 2016), with spatial resolution of 3 arc -second (90 meters), on which hydrology tools were processed from the spatial analyst extension in the ArcGIS $10.1{ }^{\circledR}$ GIS, in order to define the watercourses and delimitation of the river basin.

The landforms elements called geomorphons were obtained from the proposed (Jasiewicz; Stępiński (2013) analyzing the textural similarity of the DEM, which present variations more or less gray levels between neighboring cells, considering a specific level: if greater " 1 ", if smaller "-1" if equal "0." This is transferred to values of elevation of the terrain of greater, lesser or equal (Figure 1).

For the processing of the digital model of elevation and generation of the geomorphons, the online application was made available at the electronic address $<$ http://sil.uc.edu/geom/app $>$. The application code is also available for download at http://sil.uc.edu/. Having defined the processing in the online environment, the DEM was segmented in parts, due to the restriction of the number of cells processed.

The input file for the scan is a DEM and the two free scalar values are L lookup (distance in meters or cell units) and threshold $t$ (leveling in degrees). For the free parameters the value of $L$ was equal to 20 pixels ( 1800 meters) and degrees t equal to $2^{\circ}$.
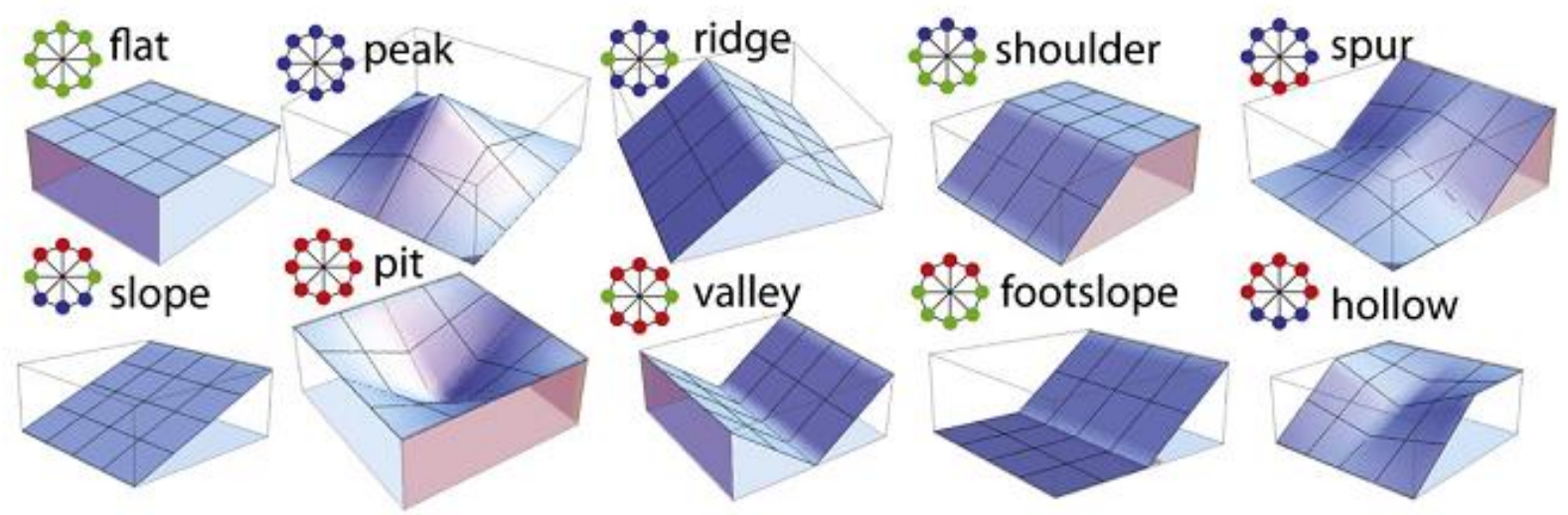

Figure 1. Geomorphons recognized in the analysis of landforms. Modified by Jasiewicz \& Stepinski (2013) 
After the generation of the landforms elements, the data were organized in GIS to define the area and percentage of each unit, as well as the occurrence of elements in each sector of the river basin.

\section{Hydrographic basin of Uruguay river}

The Uruguay river forms part, along with the Paraná and Paraguay rivers, of the hydrographic system of the "Rio de la Plata". The estuary of the Plata river is located in the Atlantic Ocean. Montevidéo, the capital of Uruguay, is on the North bank of the estuary, and Bueno Aires, the capital of Argentina, is on the Southwest bank.

According to Eduardo Navarro, "Uruguay" is a term derived from Guarani which means "river of uruguás", by the union of uruguá (type of snail of fresh water) and 'y (river) (Navarro, 2013).

The Basin of the Uruguay River occupies a total area of $365,000 \mathrm{~km}^{2}$, extending over the administrative territories of Brazil, Argentina and Uruguay (Figure 2). The area of the basin within Brazilian territory reaches $174,612 \mathrm{~km}^{2}$, with $73 \%$ in Rio Grande do Sul and 27\% in Santa Catarina (ANEEL, 2007).

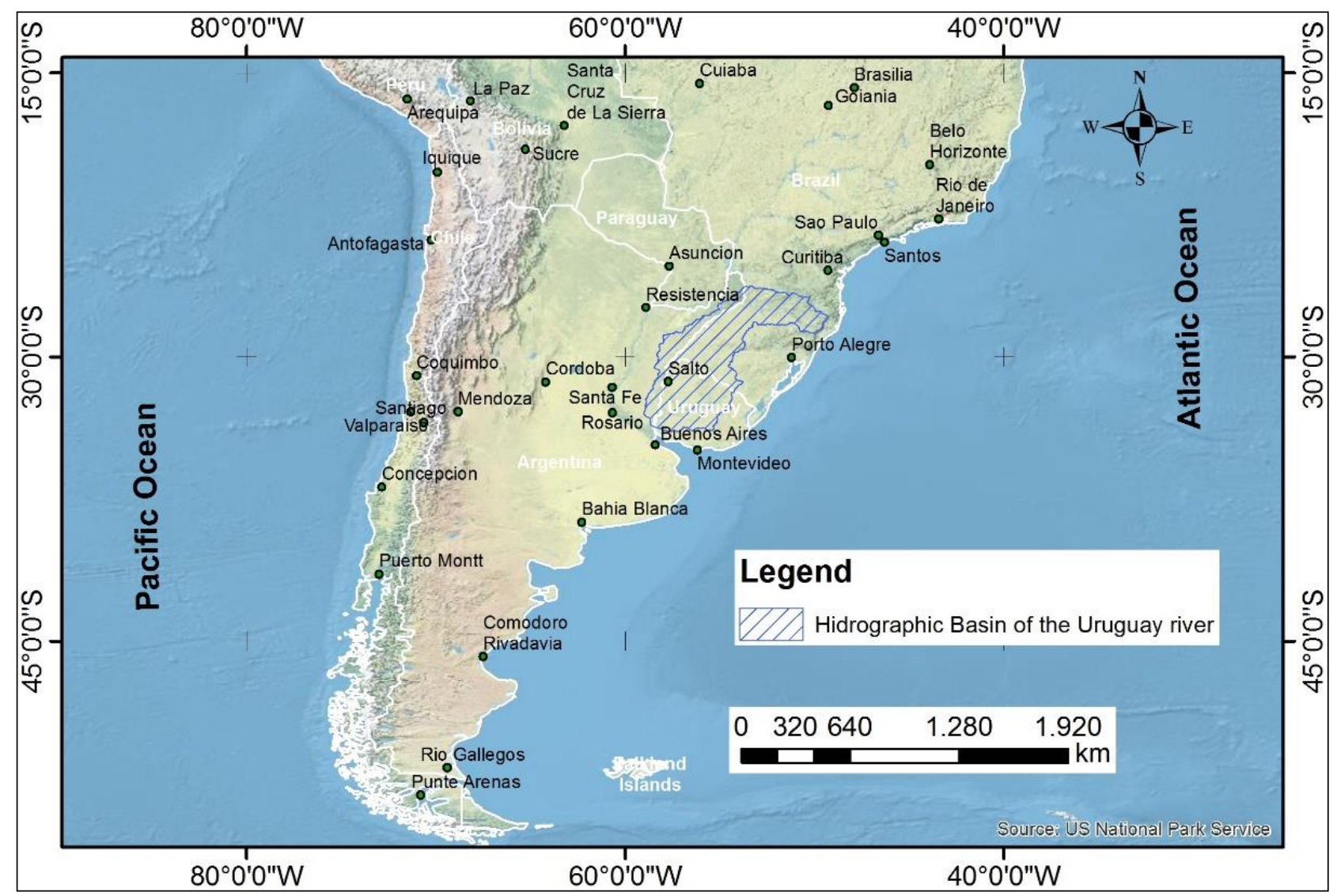

Figure 2 - Map of the location of the Uruguay River basin

From the confluence of the Pelotas and Canoas rivers, upstream, until its confluence with the Paraná River, it assumes the East-West direction, dividing the states of Rio Grande do Sul and Santa Catarina. After its confluence with the Peperi-Guaçu river (figure 03-a), it flows towards the Southwest, serving as a political border between Brazil and Argentina. In this region is the "Yucumã" waterfalls (figure 03-b), the longest longitudinal waterfall in the world, with an approximate length of $1.8 \mathrm{~km}$ and a maximum height of 20 meters.

It goes South-West until it receives the affluence of the river Quaraí, which limits Brazil and Uruguay, when it takes the South direction, where it has the role of international limit between Argentina and Uruguay, until its mouth.

In its first $500 \mathrm{~km}$, from the confluence of the Pelotas and Canoas rivers, the Uruguay river starts at a level of 447 meters, with a slope of 0.5 $\mathrm{m} / \mathrm{km}$ and reaches a quota of 170 meters in relation to sea level at the mouth of the PeperiGuaçu river.

According to (BASSO, 2004), downstream of Porto Lucena (figure 03-c), near the mouth of the Piratini River, the Uruguay River extends its valley and generates features that denote significant fluvial accumulation, determined the 
limit between the high and middle courses. In the of Uruguaina/RS (figure 03-d), located in the middle course, the width of the bed is up to $1200 \mathrm{~m}$ and the slope of the channel is approximately 0.10 meters / km (TUCCI, 1993). The middle course of the Uruguay River extends to the town of Salto/Uruguay (figure 03-e), just after the mouth of
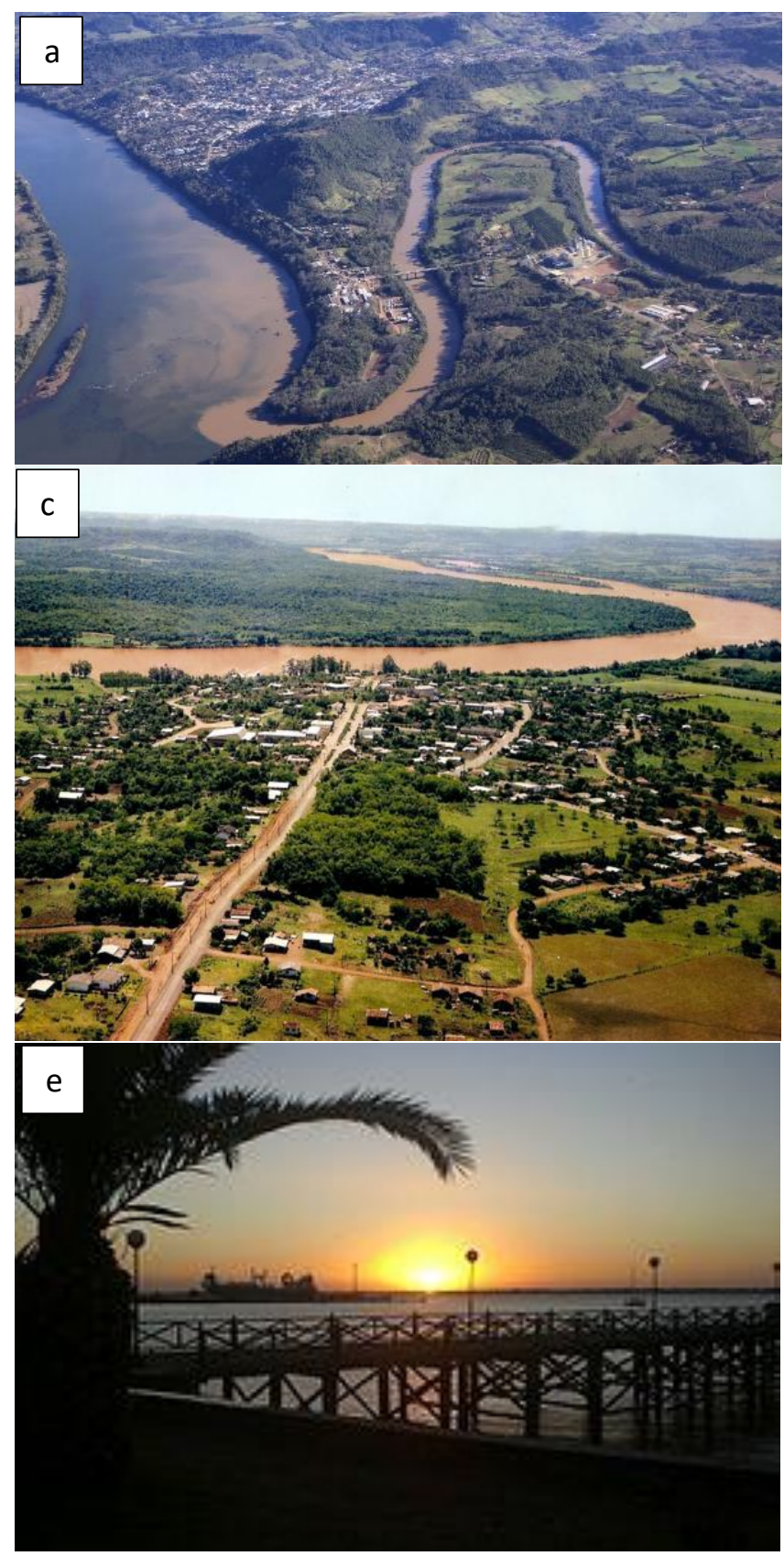

Figure 3 - Photographs of various portions of the Uruguay River

a - Peperi-Guaçu river mouth; b - Longitudinal waterfall in Uruguay river denominated "Salto do Yucumã"; c - Uruguay River along the of Porto Lucena / RS; d - International Bridge over Uruguay river linking the cities of Uruguaiana/Brazil and Paso de los Libres/Argentina; e - Uruguay river in Salto/Uruguay; $\mathrm{f}$ - mouth Uruguay river - Port of Nueva Palmira/Uruguay

the river Arapey Grande, covering an approximate extension of $550 \mathrm{~km}$.

According Tucci (1993) the remaining 377 $\mathrm{km}$ represent the lower course of the Uruguay river, where the navigation is verified in all, for a boat of 1.80 meters draft, and in the final $190 \mathrm{~km}$ for large boats, since the minimum depth there is 40 meters in Port of Nueva Palmira/Uruguay (figure 03-f)).
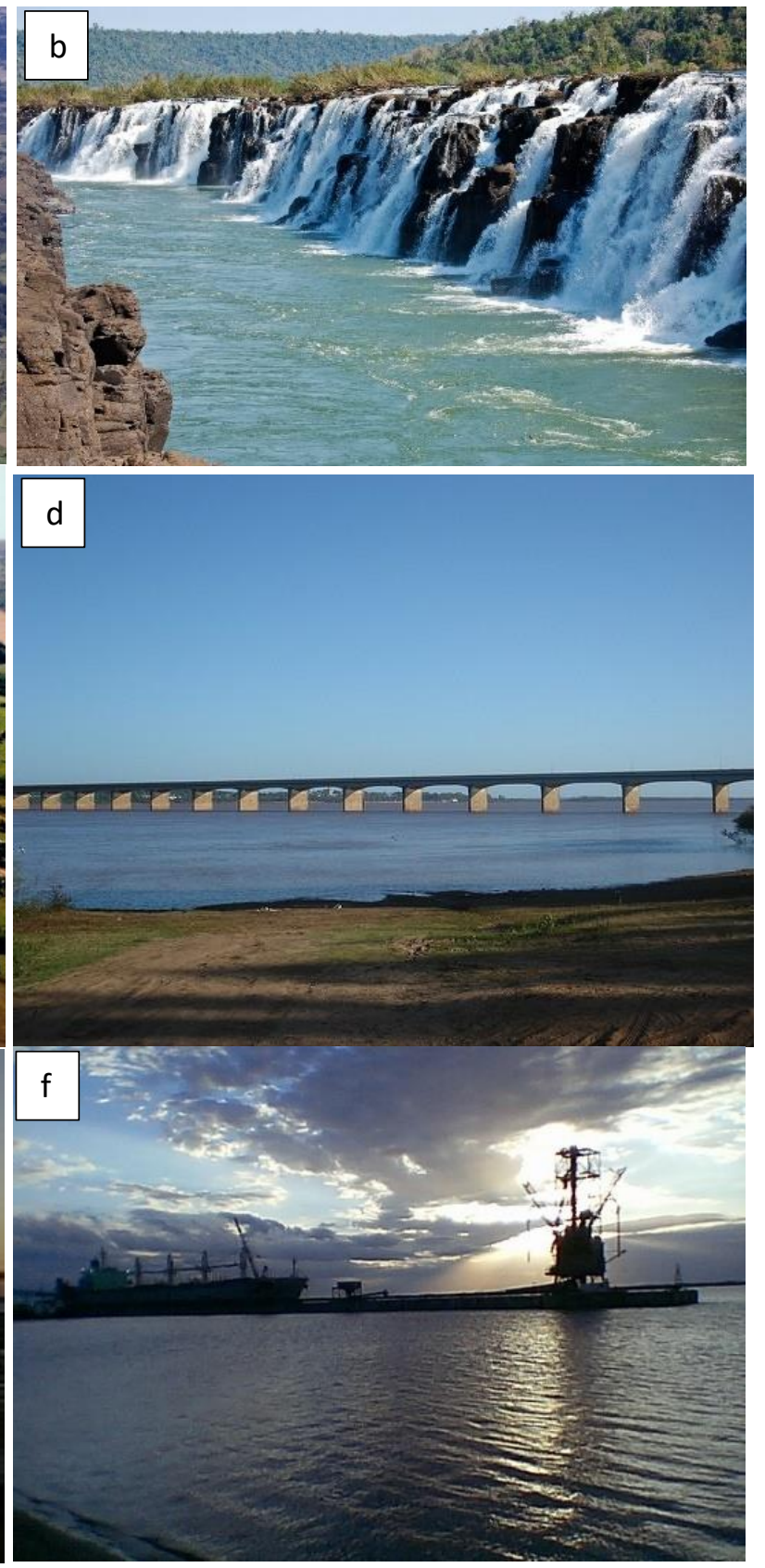


\section{LANDFORMS ELEMENTS OF THE URUGUAY RIVER BASIN \\ reaches of the Uruguay River. The table 01 shows \\ The spatial distribution of the the quantitative distribution of each element, in the basin and in the different portions of the river.} geomorphons is shown in figure 4 , where observe the distribution in the upper, middle and lower

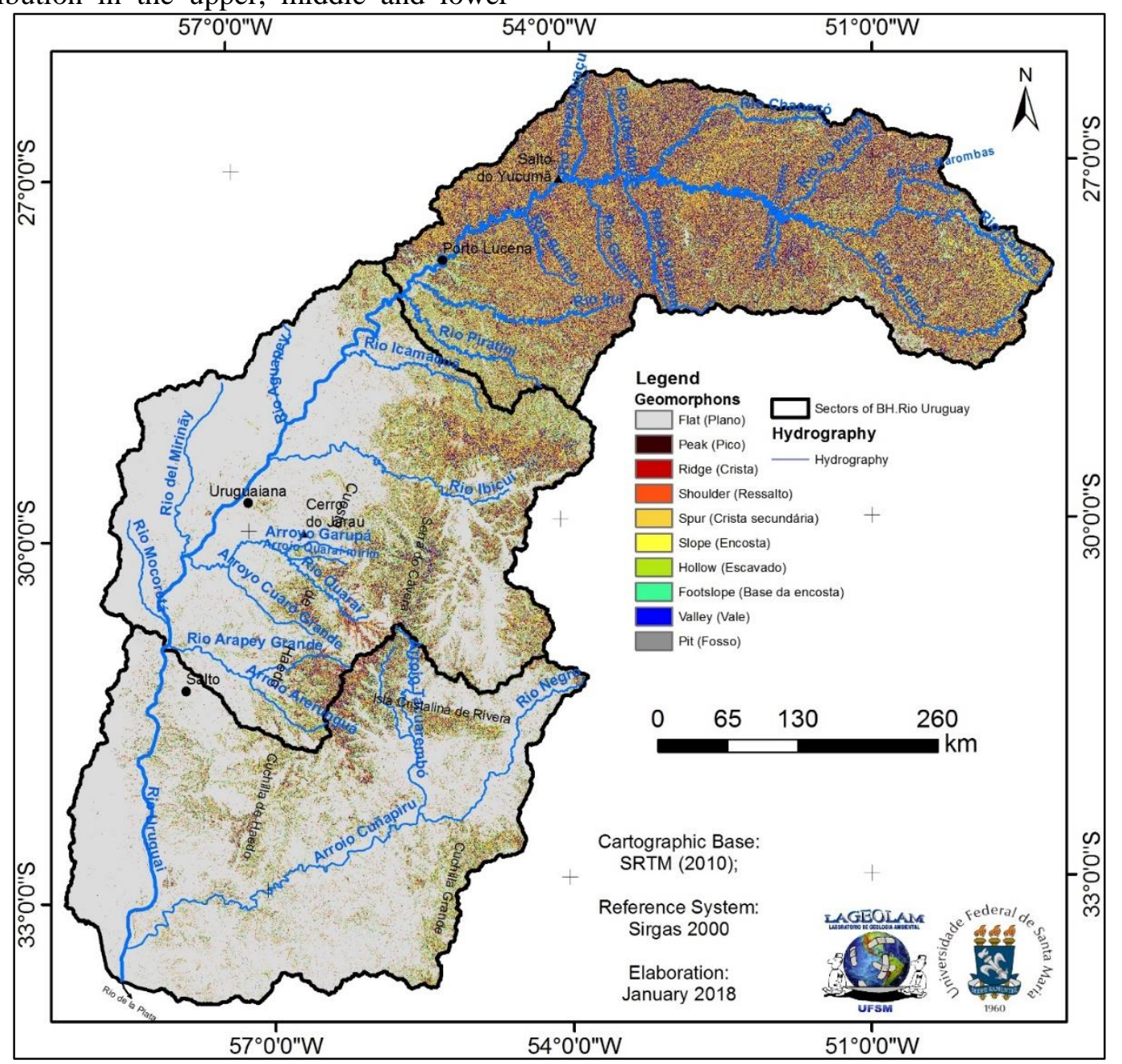

Figure 4 - Spatial distribution of the Geomorphons in the Uruguay River Basin

Table 1 - Area and percentage of the landforms elements of the Uruguay river basin

\begin{tabular}{l|l|l|l|l|l|l|l|l}
\hline Geomorphons & $\begin{array}{c}\text { Area Basin } \\
\left(\mathrm{km}^{2}\right)\end{array}$ & $\begin{array}{c}\% \\
\text { bacia }\end{array}$ & $\begin{array}{c}\text { Area high } \\
\text { course } \\
\left(\mathrm{km}^{2}\right)\end{array}$ & $\begin{array}{c}\text { \% high } \\
\text { course }\end{array}$ & $\begin{array}{c}\text { Area middle } \\
\text { course }\left(\mathrm{km}^{2}\right)\end{array}$ & $\begin{array}{c}\% \\
\text { middle } \\
\text { course }\end{array}$ & $\begin{array}{c}\text { Area low } \\
\text { course } \\
\left(\mathrm{km}^{2}\right)\end{array}$ & $\begin{array}{l}\% \text { low } \\
\text { course }\end{array}$ \\
\hline Flat & $176.545,77$ & 51,04 & $5.132,86$ & 4,50 & $83.793,82$ & 68,83 & $87.619,26$ & 79,53 \\
\hline Peak & $2.669,97$ & 0,77 & $2.184,30$ & 1,92 & 327,24 & 0,27 & 158,43 & 0,14 \\
\hline Ridge & $25.426,11$ & 7,35 & $18.814,16$ & 16,51 & $4.299,28$ & 3,53 & $2.312,71$ & 2,10 \\
\hline Shoulder & $21.193,87$ & 6,13 & $6.339,53$ & 5,56 & $8.186,60$ & 6,72 & $6.667,78$ & 6,05 \\
\hline Spur & $19.784,02$ & 5,72 & $16.213,17$ & 14,23 & $2.628,23$ & 2,16 & 942,62 & 0,86 \\
\hline Slope & $34.511,10$ & 9,98 & $23.407,45$ & 20,54 & $7.632,34$ & 6,27 & $3.471,30$ & 3,15 \\
\hline Follow & $13.915,28$ & 4,02 & $11.423,75$ & 10,02 & $1.842,06$ & 1,51 & 649,48 & 0,59 \\
\hline Valley & $20.427,45$ & 5,91 & $5.507,80$ & 4,83 & $8.429,89$ & 6,92 & $6.489,77$ & 5,89 \\
\hline Pit & $28.562,53$ & 8,26 & $22.242,92$ & 19,52 & $4.485,98$ & 3,68 & $1.833,62$ & 1,66 \\
\hline
\end{tabular}


The distribution of geomorphons show the variation of a very bustling landforms in the high course for dissected landforms constituted of smoothly undulating areas, for medium and low course.

The flat element is predominant in the basin, with $51.04 \%$ of the total area, characterizing a gently undulating to plane landforms in most of the basin area. The slope element is associated with relief of rolling hills and buttes, occurring around $10 \%$ of the basin. Associated with the slope occurs the valley element with $8.26 \%$ of the total area of the basin. In the basin, the fourth most important element of the landforms is the ridge which comprises $7.35 \%$ of the total. The shoulder element occurs in $6.13 \%$ of the basin, forming "cornijas" on medium slopes. Associate a smoothly undulating landform occurs the footslope element with $5.91 \%$ of the total basin. At the top of the slopes, next to the ridge element, forming secondary the spur element with $5.72 \%$ of the total of the basin. The hollow element occurs in $4.02 \%$ of the basin, marking portions with incisions on the slopes in the process of stream erosion. Occurring associated to the elements ridge, spur and shoulder, are present the elements pit and peak, with $0.83 \%$ and $0.77 \%$, respectively, of the total basin.

\section{High course of the Uruguay river}

In the high course Uruguay River, the flat element is not very representative, corresponding to $4.5 \%$ of the total area. The flat elements, represented by flattening surfaces, generally developed over areas in the interfluvial positions. These flattening surfaces are processed by pediplanation as a result of successive erosive attacks.

Most of the high course area is characterized by landforms generated to differential dissection, translated by deep river that have built-in structural lines on a substrate characterized in acidic and basic volcanic rocks. Thus, elements such as slope, with $20.54 \%$, which is $19.52 \%$ valley and ridge with $16.51 \%$ are the most important of the high course (figure 05-a and b).

The connections between the elongated tops of the hills are represented by the spur element, which in the high course is an important element with $14.23 \%$ of the total area. Gully that mark the slope, connected or not in the drainage network, are represented by hollow element, occurring in $10.02 \%$ of the area.

Elements such as peak and pit are present, dominantly, in the high course, where it represents $1.92 \%$ and $2.38 \%$ of the total area, respectively.

\section{Middle course of the Uruguay river}

Streams begin to meander across the wider valley floor. Downcutting is greatly reduced, and thereafter both erosion and deposition combine to reduce local relief (Figures 6 and 7). 

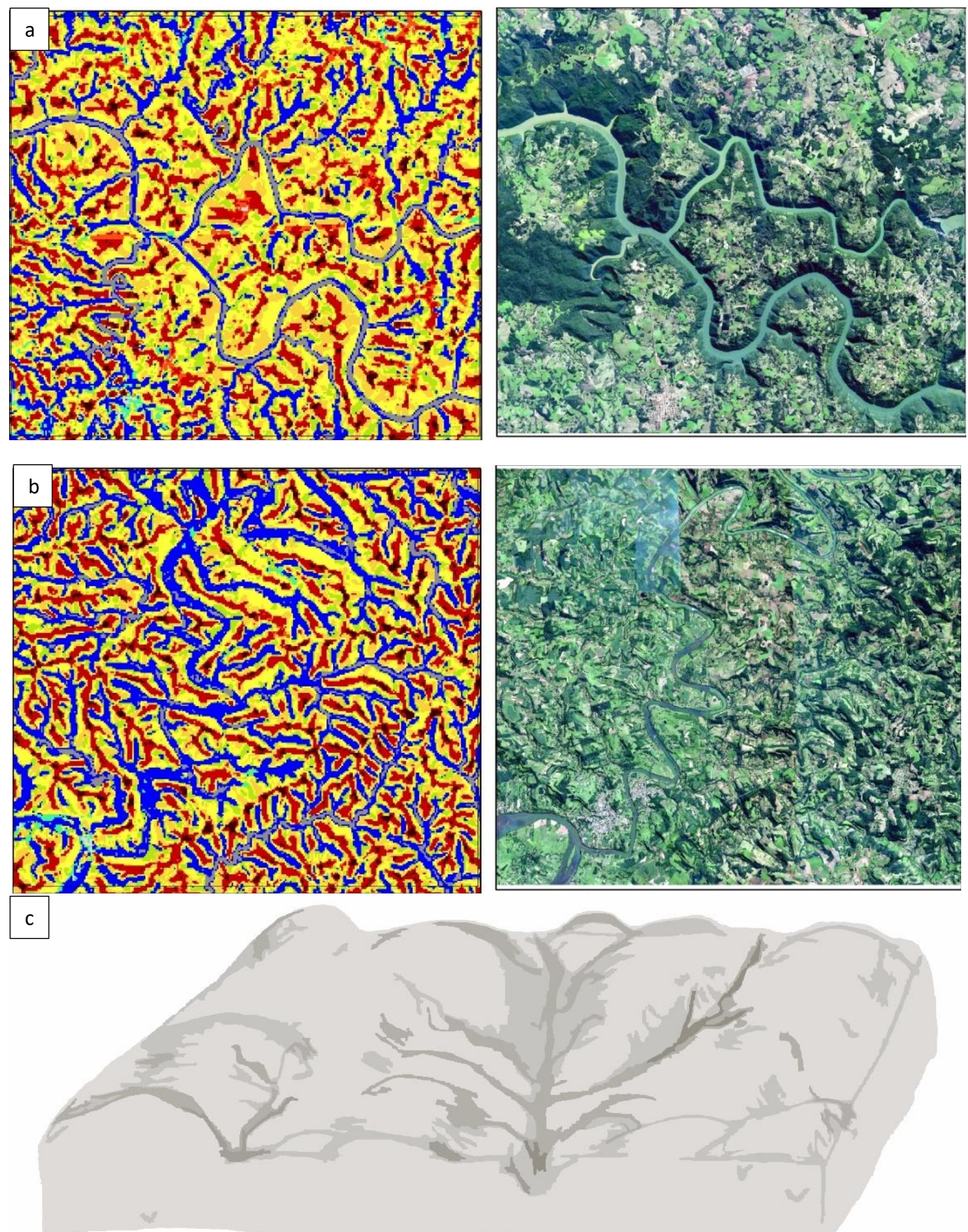

Figure 5 - Elements of geomorphons in the High course of the Uruguay river. a - Landscape in the high course presenting the encounter of the river Pelotas and Canoas,formators of the Uruguay river. Note the large slope elements with ridge and shoulder at the top and half slope cut by embedded valleys. $b$ - Landscape on high course, Cascavel river. Landforms with large slopes and wider ridges together with the river valley and in the more distant areas the short slopes cut by narrow valleys. $\mathrm{c}$ - Schematic drawing of the landscape on the high course. 

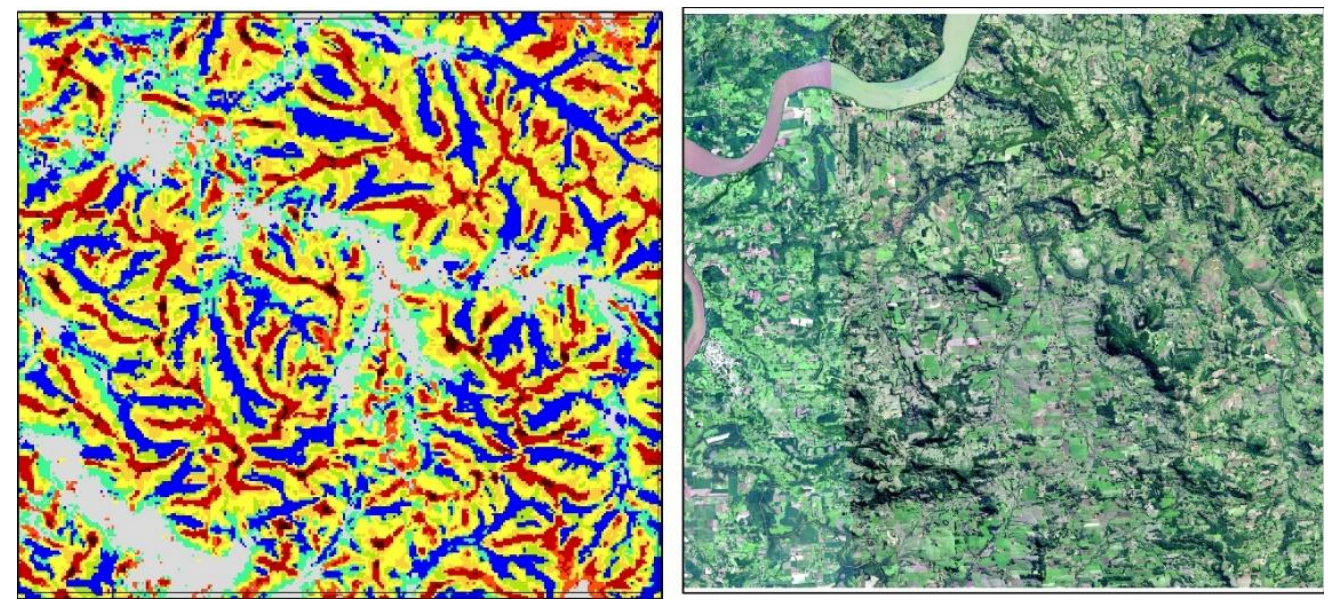

Figure 6 - Landscape in the passage from the upper course to the middle course, the Piratini river basin. The valleys become wider and the flat and footslope elements are common.

Therefore, the flat element significantly increases its occurrence in the middle course, when it passes to $68.83 \%$. It is represented by a flat, subhorizontalized morphology with a gentle slope to the west, over the extensive terraces of the Uruguay River on the left bank, and by extensive flat areas formed by Pleistocene sediments on the right bank (Ramos,1999)

In the middle course the slope elements, with $6.27 \%$, valley, with $3.68 \%$, and ridge, with $3.53 \%$ occur associated the basin of the Ibicuí river, forming a relief of buttes and hills that constitute

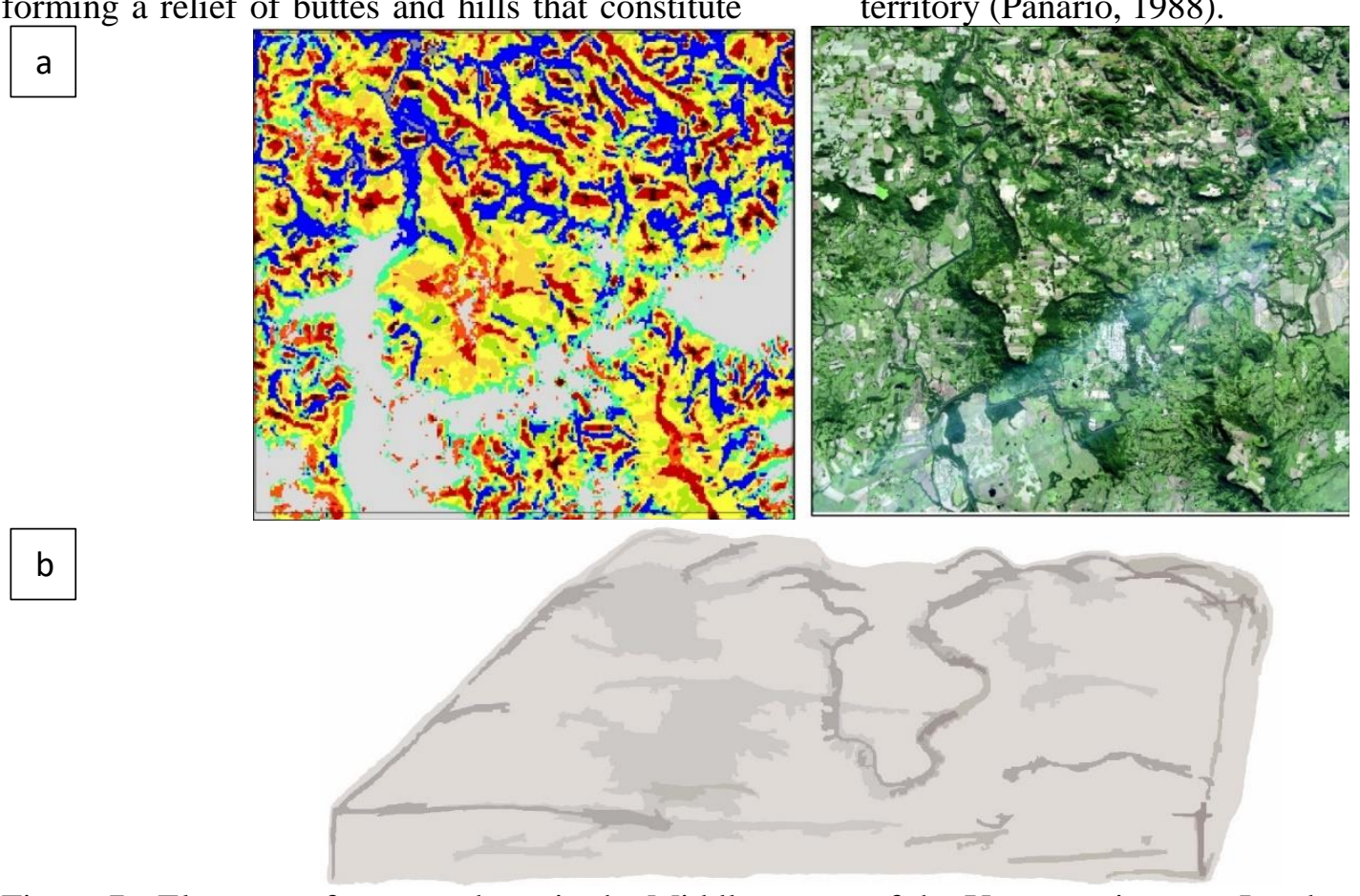

Figure 7 - Elements of geomorphons in the Middle course of the Uruguay river. a - Landscape in the middle course, near the Plateau border that marks the contact of flat areas with busy relief formed by slopes, crests and valleys. The flat top elevation is well represented by shoulder elements around the flat element. b Schematic drawing of the landscape on the Plateau border abrupt elevation produced by dissecation of the Plateau.

In addition, they are represented in an important feature of the relief, in the middle course, which is "Serra do Caverá" (figure 8). This landforms corresponds to the interflow between the Ibicuí and Quaraí rivers, which has its abrupt terminal to the East, forming a front of cuesta towards to lowland of the Rio Ibicuí-Rio Negro Depression, known as the "Cuesta Haedo" (figure 9), which has its greatest extension in Uruguay territory (Panario, 1988). 


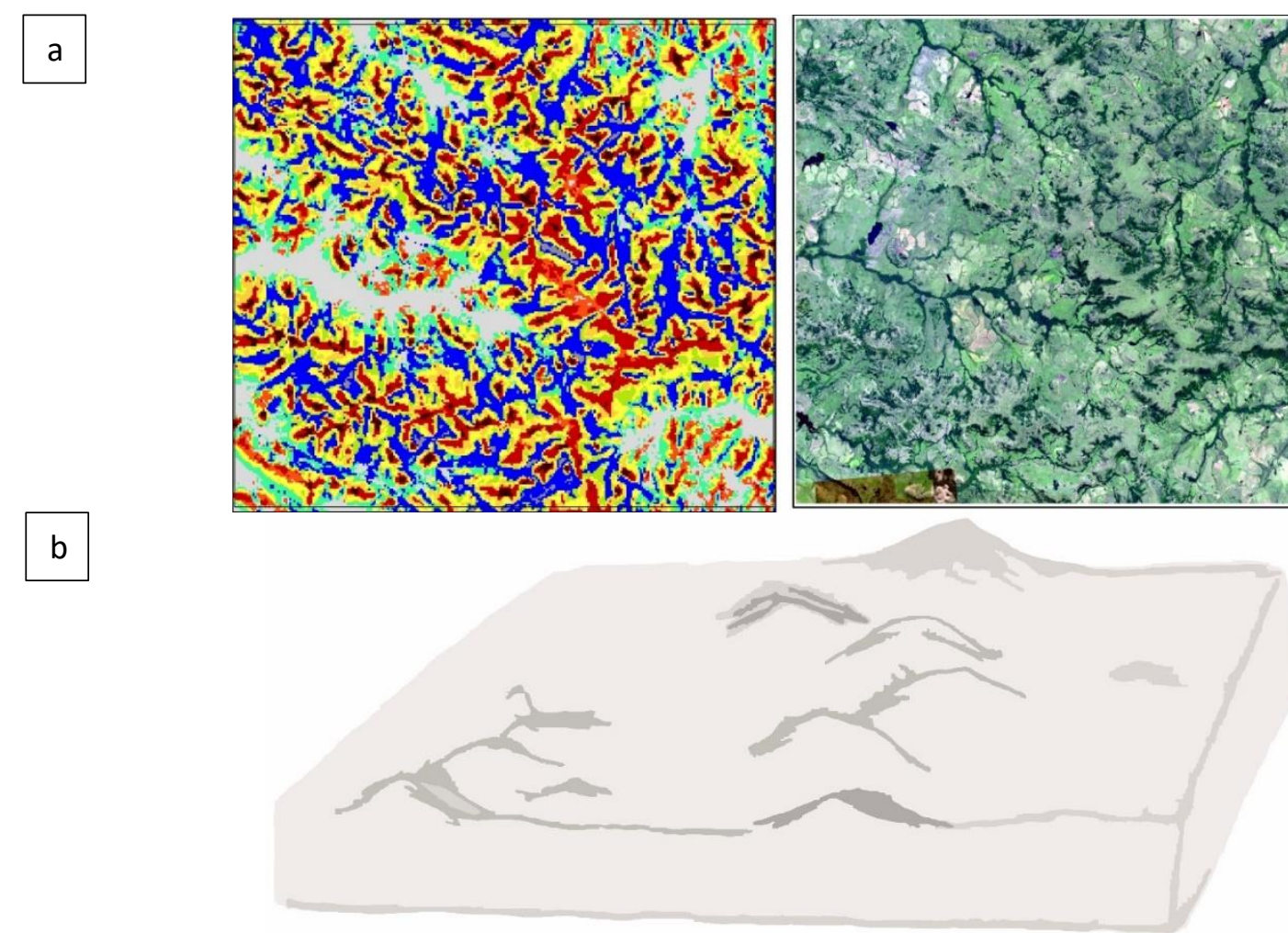

Figure 8 - Elements of geomorphons in the Serra do Caverá. a - Landscape in the middle course in the area defined as Serra do Caverá. Represented by an association of small elevations, defined for ridge, shoulder and short slope, cut by valleys in a region of relief planes to gently undulating as seen in the elements flat and footslope. $b$ - Schematic drawing of the landscape in the Serra do Caverá

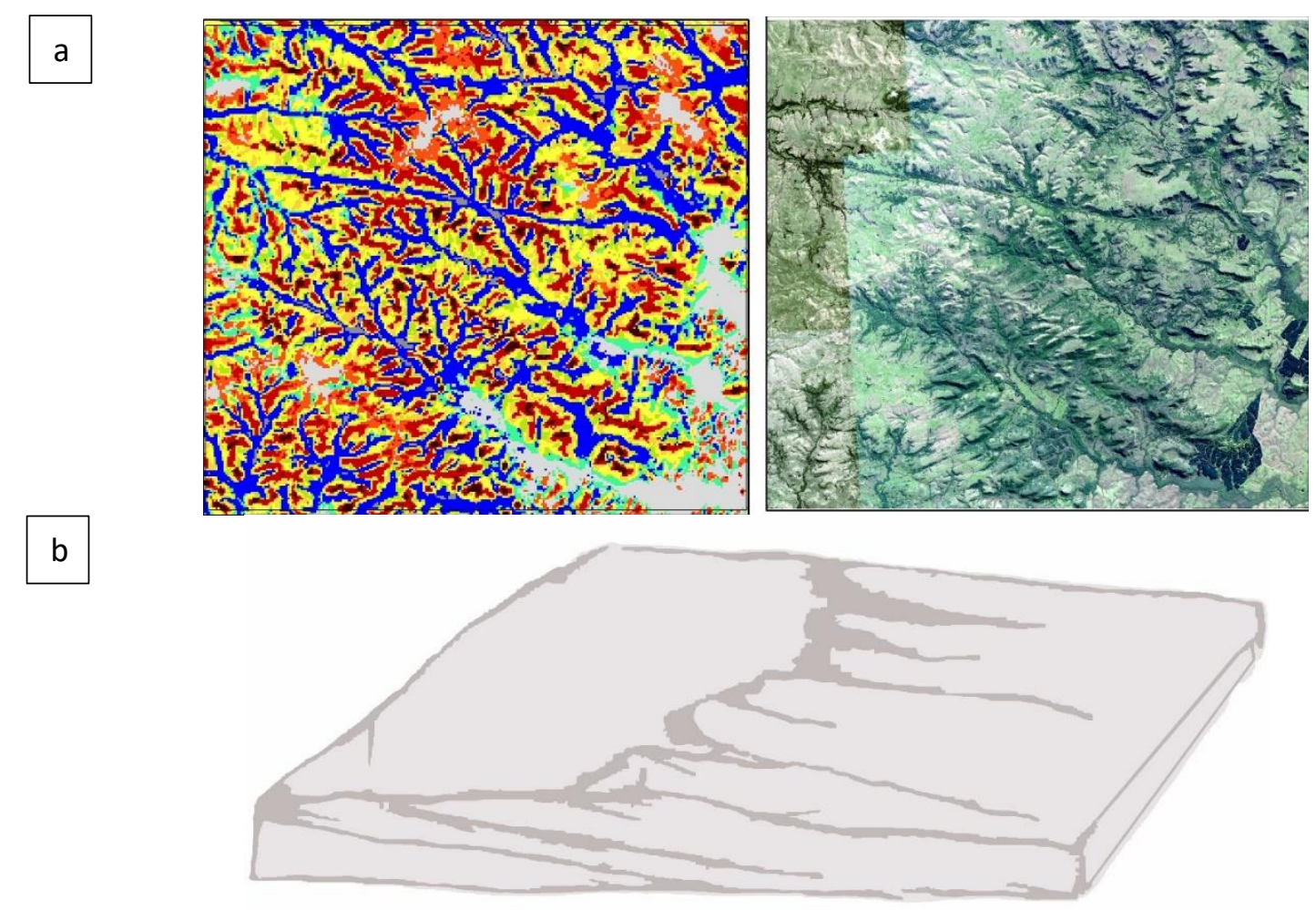

Figure 9 - Elements of geomorphons in the Cuesta de Haedo. a - Area that represents the front of Cuesta de Haedo. Occurs in the high course of the Negro River with elements showing the effect of remontant erosion of friable materials of the underlying sandstones, characterized by the occurrence of lava with horizontal structures, which generate flattened forms discontinuous by the presence of steep areas due to erosive resistance. $\mathrm{b}$ - Schematic drawing of the landscape in Cuesta de Haedo 
The slope element is also associated with flattopped elevation know by mesa and meseta, which constitute a series of residual reliefs.

Shoulder is significant elements in the middle course $(6.72 \%)$. The sandstone " intertraps" often appears in discontinuous stretches on the slopes and cliffs.

Footslope is an important element in the dissected relief of the medium course $(6.92 \%)$ associated to the landforms of soft hills.
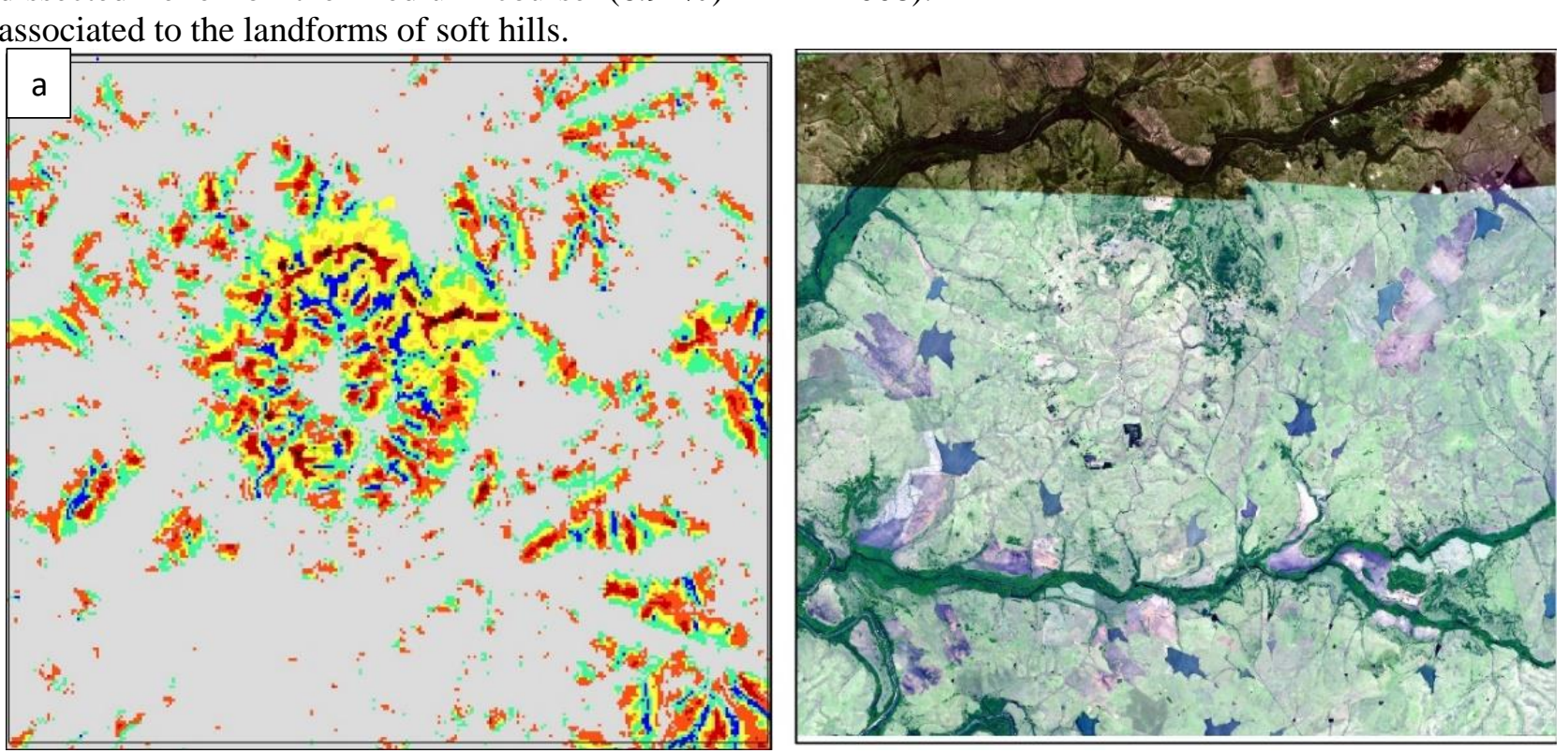

In the middle course of the Uruguay River, on the left bank, in the interfluvial area of the Quaraí-Mirim and Garupá rivers, an expressive geomorphological feature, marked by elements of slope and shouder, represented by a residual landforms called "Cerro do Jarau" (figure 10). This form has been worked out in the geological literature as an astroblem (Crósta \& Lourenço, 2008).

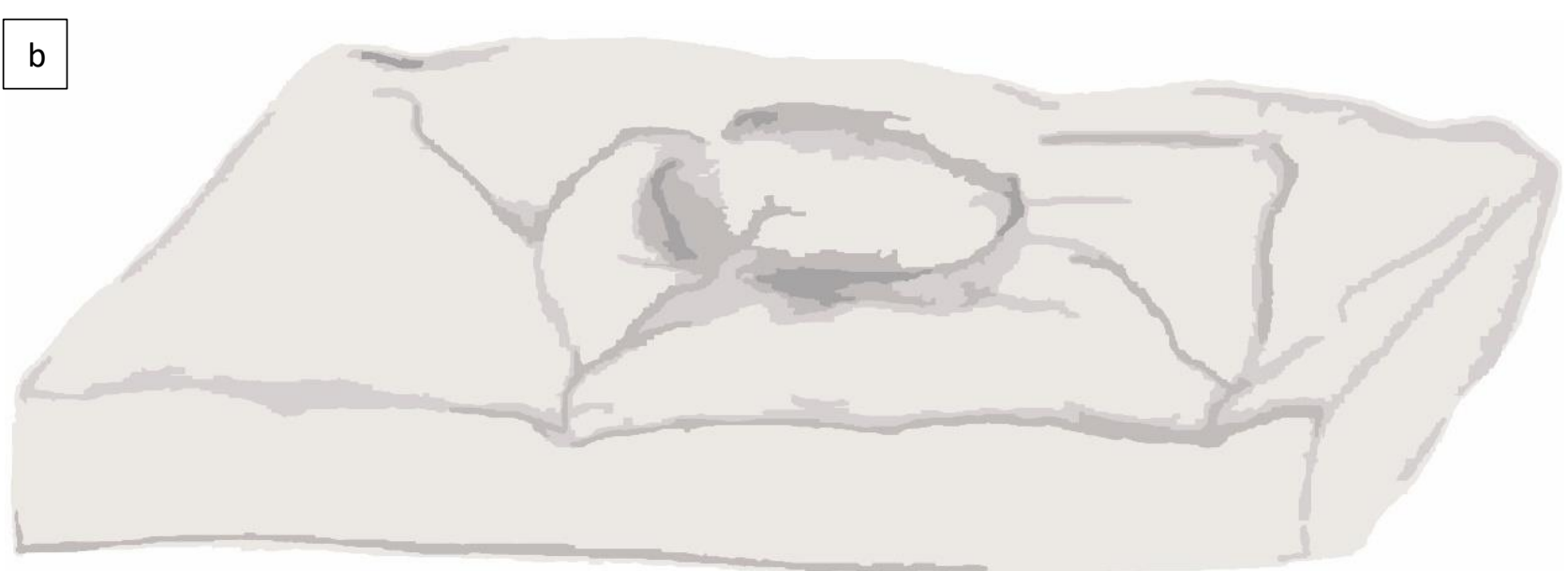

Figure 10 - Elements of geomorphons in Cerro do Jarau. a - Feature observed in the middle course that presents well marked by slope and ridge and shoulder geomorphons. Semi circular area, on the border of the Quaraí river basin, called Cerro do Jarau. This form has been worked out in the geological literature as an astroblem. b - Schematic drawing of the landscape of the Cerro do Jarau.

\section{Low course of the Uruguay river}

The right bank, located in Argentina, forms flat areas with sediments composed of fluvial deposits, sandy and silts deposits associated with eolian and lacustrine deposits of the Pleistocene (Ramos,1999). The landscape in low course is reduced to a low, almost featureless surface near 

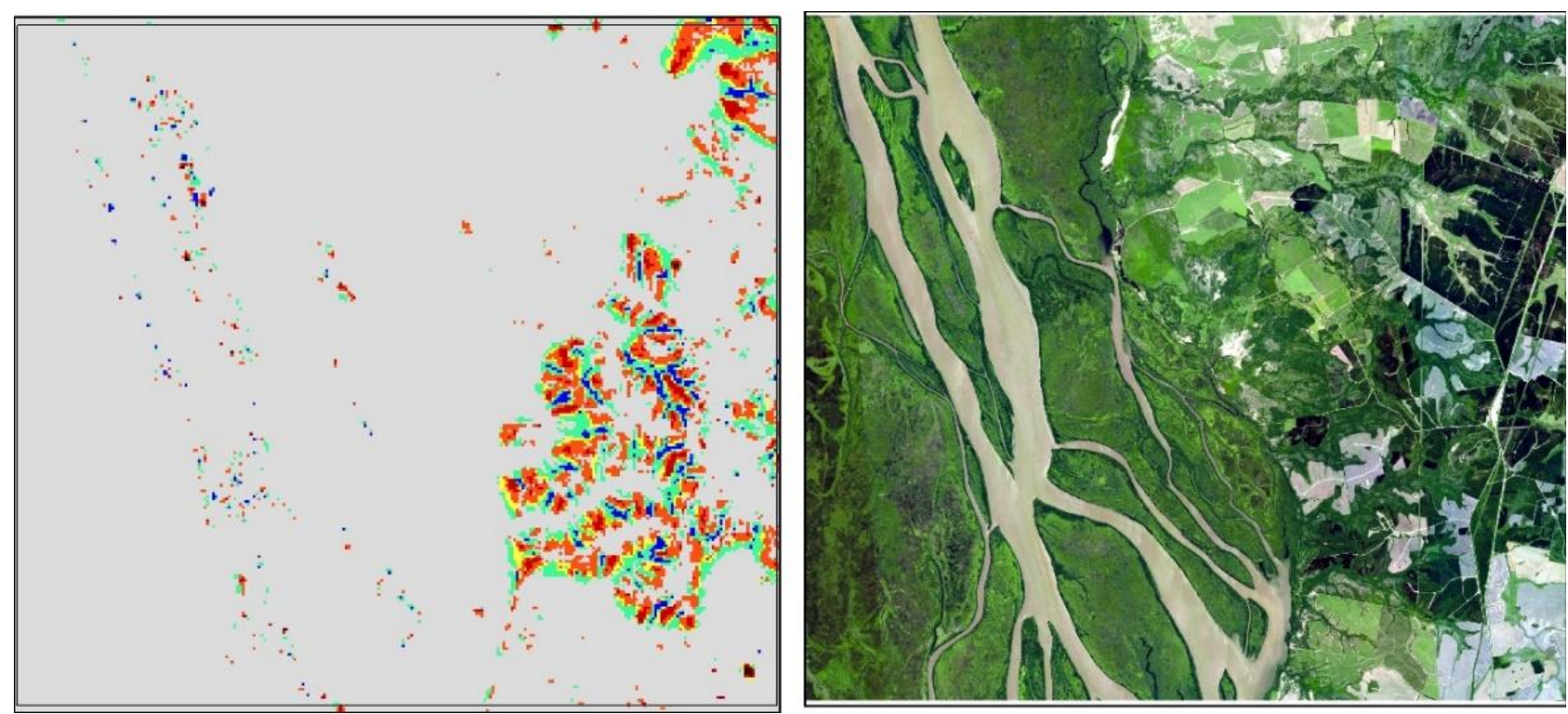

Figure 11 - Landscape of the mouth of the river Uruguay marked by flat elements and some soft elevations with the presence of shoulder and footslope

In the left bank, within Uruguay territory, to the north in Mesozoic volcanic rocks, and to the south, crystalline rocks of the geological basement were eroded and planed during the final stage of the Tertiary and Early Quaternary. Later, during the Quaternary period, these areas received sediments of fine sandstones and carbonate siltstones, interpreted as being of continental origin in the semi-arid environment of the Oligocene (Preciozzi et al, 1985).

Locally erosional remnants of resistant bedrocks may rise above the peneplain surface. They form areas with elements of slope, with $3.15 \%$, valley with $1.66 \%$ and ridge, with $2.1 \%$, in the low course. They occur in the headwards of the Rio Negro where the predominance of more resistant materials form a high topographic known as "Cuchilla Haedo" composed by volcanic rocks and sandstone sedimentary rocks and also in the crystalline basement, form a Precambrian basement window located in northern of Uruguay "Rivera Crystalline Island" (Quadros, et al.2002). In front of the regression of the basaltic Cuesta there are shoulders represented by $6.05 \%$ of the area.

\section{Final considerations}

The increasing development of geotechnologies provides the incorporation of procedures and techniques that aid in the analysis of the landforms, through the interpretation of digital elevation models, that aid in the understanding of the compartmentalization of the relief.
At the core of the method used in search is the concept of geomorphon (geomorphologic phonotypes) - a simple ternary pattern that serves as an archetype of a particular terrain morphology.

As a result, the method classifies the elements of the basin of the Uruguai river into a variety of different elements of the landforms with computational efficiency.

In the Basin of the Uruguai River the variation of landforms in the high course for dissected landforms of medium and low course, is very well represented by the geomorphons. The element flat is predominant in the basin, with $51.04 \%$ of the total area, characterizing a gently undulating to plane landforms in most of the basin area.

Geomorphometric maps generated using the method provide an input for pattern-based query tool capable of identifying all local landscapes similar to a given reference.

\section{References}

ANEEL. 2007. Agência Nacional De Energia Elétrica. Bacias Hidrográficas do Brasil. Disponível em: <http://www.aneel.gov.br/111.htm>. Acesso em: 4 ago. 2007.

Basso, L. A. 2004. Bacias hidrográficas do Rio Grande do Sul: implicações ambientais. In: UFRGS Editora (Ed.). . Rio Grande do Sul: Paisagens e territórios em transformação. $2^{\mathrm{a}} \mathrm{ed}$. Porto Alegre: 2014, p. 319. 
Crósta, A. P; Lourenço, F. S. 2008. Proposta de Sítio Geológico ou Paleobiológico do Brasil Astroblema de Cerro do Jarau, RS. Comissão Brasileira de Sítios Geológicos e Paleobiológicos (SIGEP).

Dragut, L.; Blaschke, T. 2006. Automated Classification of Landform Elements Using Object-Based Image Analysis. Geomorphology 81, 330-344.

Instituto Brasileiro De Geografia E Estatística (IBGE). 1986. Projeto RADAMBRASIL. Levantamento de recursos naturais (Folha SH.22 Porto Alegre e parte das Folhas SH.21 Uruguaiana e SI.22 Lagoa Mirim). Instituto Brasileiro de Geografia e Estatística, Rio de Janeiro, CD-ROM.

Instituto Brasileiro De Geografia E Estatística (IBGE). 2010. Malhas Digitais. Municípios 2010, Rio de Janeiro, Disponível em <http://downloads.ibge.gov.br/downloads_geo ciencias.htm> Acesso junho de 2015. .

Iwahashi, J.; Pike, R. J. 2007. Automated Classifications of Topography from DEMs by an Unsupervised Nested-means Algorithm and a Three-part Geometric Signature. Geomorphology 86, 409-440.

Jasiewicz, J.; Stepinski, T. F. 2013. Geomorphons a Pattern Recognition Approach to Classification and Mapping of Landforms. Geomorphology 182, 147-156.

Liao, W. H. Region Description Using Extended Local Ternary Patterns. 20th International Conference on Pattern Recognition, 2010. pag. 1003-1006.

Macmillan, R. A.; Shary, P. A., Landforms and landform elements in geomorphometry. In: HENGL, T. e REUTER, H. I. (eds), Geomorphometry-Concepts, Software, Applications. Developments in Soil Science, Amsterdam Elsevier, 2009. vol. 33. pag. 227254.

Muñoz, V. A. Análise geomorfométrica de dados SRTM aplicada ao estudo das relações solorelevo. Instituto Nacional de Pesquisas Espaciais, São José dos Campos, 2009. 112p. (INPE-15796-TDI/1531). Dissertação (Mestrado em Sensoriamento Remoto). Instituto Nacional de Pesquisas Espaciais.

Navarro, E. A. Dicionário de tupi antigo: a língua indígena clássica do Brasil. São Paulo. Global. 2013. p. 606.
Panario, D. Geomorfología del Uruguay, Propuesta de un marco estructural y un esquema de evolución del modelado del relieve uruguayo. Departamento Publicaciones - Facultad de Humanidades y Ciencias, UdelaR, Montevideo. 32 p. 1988

Panario. D,; Gutierrez, O,; Achkar, M,; Bartesaghi L.; Ceroni M. Clasificación y mapeo de ambientes em Uruguay. Informe Técnico. Convenio MGAP/PPR - Facultad de Ciencias/Vida Silvestre/Sociedad Zoológica del Uruguay/CIEDUR. 149p. 2011.

Porta, F. P.; Piioppo, J. S.; Marziotto, W. H.; Kempa, P. R. Memoria explicativa de la carta geológica del Uruguay a la escala 1:500.000. Montevideo: Ministerio de industria y energía. Dirección nacional de minería y geología. 1985.

Preciozzi, F., J. Spoturno, W. Heinzen, P. Rossi. 1985. Memoria explicativa de la Carta Geológica del Uruguay del Uruguay a la escala 1:500.000. Montevideo, Dirección Nacional de Minería y Geología (DINAMIGE), Ministerio de Industria, Energía y Minería, Montevideo. 92 p., il; 2 mapas fuera de texto.

Ramos, Víctor A. 1999. Caminos, R., Geología argentina (Instituto de Geología y Recursos Minerales, Anales 29 (24): 715-784

Schmidt, J.; Hewitt, A. Fuzzy land element classification from DTMs based on geometry and terrain position. Geoderma, v. 121, n. 3, p. 243-256, 2004.

Silveira, R. M. P.; Silveira, C. T. 2015. Classificação hierárquica automatizada de formas do relevo no estado do Paraná apoiada na modelagem digital do terreno. Revista Brasileira de Geografia Física 8, 1509-1523.

Silveira, R. M. P.; Silveira, C. T. 2016. Da. Análise Digital Do Relevo Aplicada À Cartografia Geomorfológica Da Porção Central Da Serra Do Mar Paranaense. Revista Brasileira de Geomorfologia $17.616-629$. DOI: http://dx.doi.org/10.20502/rbg.v17i4.106 $\underline{3}$

Telmo F. P. De Quadros; Jair C. Koppe; Adelir J. Strieder; João Felipe C. L. Costa. 2002. Arcabouço Estrutural da Ilha cristalina de Rivera (Uruguai) e sua implicação na potencialidade mineral. Rem, Rev. Esc. Minas vol.55 no.1 Ouro Preto Jan./Mar. 
Revista Brasileira de Geografia Física v.11, n.06 (2018) 2081-2093.

Tucci, C. E. M. Controle de enchentes. In: ABRH/EDUSP (Ed.). . Hidrologia: ciência e aplicação. Porto Alegre: [s.n.]. p. 145.
Wood, J. 1996. The Geomorphological Characterization of Digital Elevation Models. Ph.D. Thesis, Department of Geography, University of Leicester, UK. 